\title{
How Migrant Networks Facilitate Trade: Evidence from Swiss Exports
}

\author{
Pierre-Louis VÉzina ${ }^{a}$
}

JEL-Classification: F22, F14, D73, D8

Keywords: trade, migration, corruption

\section{Introduction}

International trade flows are affected by a wide array of formal and informal barriers such as transport costs and corruption. A large, albeit recent, literature has devoted special attention to the role of migrant networks in overcoming trade barriers. Following the seminal work of Gould (1994), many studies found a positive correlation between migration and trade using augmented gravity models. These suggested migrant networks facilitate trade by providing product information, enforcing contracts, and via a demand for home-country products. Still, identifying the causality and the mechanisms at work remains an ongoing challenge.

In this paper I dig into the mechanisms by looking at the protrade effect of immigrants in Switzerland, which provides high-quality immigration data. I add to the literature in two major ways. First I use two novel instrumental variables, namely immigration in France and Swiss visa restrictions, to identify the direction of causality and exploit the cross-country variation in the levels of migration and exports. Second, I bring together four methods from the previous literature to separate the underlying mechanisms. I decompose exports into an extensive margin, i.e. the number of exported products, and an intensive one, i.e. the average value of exports, as in Peri and Requena (2010). This allows me to check whether migrants reduce fixed or variable trade costs. I focus on the migrant effect on exports, rather than imports. This allows me to get rid of the "demand" effect, i.e. immigrants' preferences for home products, as first suggested by Gould (1994). I interact the migrant variable with the level of corruption in the country of origin as in Dunlevy (2006) to examine how migrant

a OxCarre and Department of Economics, University of Oxford.

pierre-louis.vezina@economics.ox.ac.uk 
networks can substitute for institutions. Finally, as in RaucH and Trindade (2002), I decompose exports into homogenous goods, i.e. goods sold on organised markets such as gold, reference-priced goods, i.e. goods with prices quoted in trade publications such as chemical products, and differentiated goods, i.e. all the rest, which are information-intensive. This allows me to separate the "information" and "contract-enforcement" effects.

I find robust evidence of a significant protrade effect of immigration only on the number of exported goods, not on the average value of exports. This result, which is robust to an alternate definition of the intensive margin and to various estimation methods, confirms Peri and Requena's (2010) finding that migrants reduce beach head costs rather than variable costs. It implies that a 10\% increase in immigration can increase the number of exported goods to the source country by as much as $1.5 \%$. For example, if the Peruvian immigrant population increased from 3000 to 10000 , about the size of the Chinese community in 2009, Switzerland would start exporting as many as 30 new SITC 4-digit categories of products to Peru.

Moreover, I find that the effect on the number of exported products is significantly larger when corruption is prevalent in the destination country, and almost inexistent when corruption is uncommon. However, this substitution effect does not appear for goods sold on organised exchanges. This pattern holds when using various institutional quality measures and when using various estimation methods including IV-Poisson (Mullahy, 1997), IV-2SLS, OLS, Poisson and negative binomial regressions.

These findings can be interpreted in two different ways. One interpretation is that migrants substitute for institutions through their information effect, not a contract-enforcement effect. Another is that differentiated goods are not only search-intensive, as commonly defined, but also trust-intensive. This would suggest RAUCH and TRINDADE's (2002) product-differentiation method is not adequate to identify information costs. Either way, this also involves that migrants promote homogenous exports through a mechanism formal institutions cannot substitute for.

The remainder of the paper is structured as follows. The next section reviews the literature and describes the theoretical mechanisms. A third section presents the empirical strategy and data. The results are discussed in the fourth section. A fifth section presents some robustness checks. A last section concludes. 


\section{Literature Review}

Ever since Gould (1994) showed empirically that immigrants' ties to their home countries played a key role in fostering the US' bilateral trade linkages, researchers have been updating and generalising his results. Herande and SaAvedra (2005), Dunlevy (2006), Bandyopadhyay et al. (2007), and White and Tadesse (2008) used US data to confirm the importance of migrant networks in increasing US exports. Head and Ries (1998) found some evidence for Canada, Girma and Yu (2002) for the UK, White (2007) for Denmark, Hatzigeorgiou (2010) for Sweden, Koenig (2009) for France, Peri and Requena (2010) for Spain, Tai (2009) and Kandogan (2009) for Switzerland, and Felbermayr and Toubal (2008) for OECD countries (see the latest wide-ranging literature review in EGgER et al., 2012).

The literature has put forward three main channels through which migrants increase trade. The first is the information channel. Missing information about available products and tastes results in a search for the right differentiated products that increases trade costs and reduces trade (RAUCH, 1996). By providing specific knowledge about products' supply and demand, migrant networks can lower the informational frictions and render trade feasible.

The second is the trust or contract-enforcement channel. One reason why so little trade occurs with developing countries is that their low quality of governance and corrupt officials affect risk perceptions (ANDERson and MARCOUILLER, 2002). When there is a high degree of uncertainty about contract enforcement, a high level of trust is required for transactions to happen (Guiso et al., 2009). Migrant networks provide this trust through cultural proximity, repeated transactions, and knowledge of implicit business rules.

The third is the demand channel. As Gould (1994) noted, migrants may have a strong preference for products from their origin country. This is known as "nostalgia trade". Hence, the export elasticity reflects a network effect while the import elasticity also includes a demand effect. Felbermayr and Toubal (2008) find that the demand effect amounts to up to $63 \%$ of the total effect.

This paper mostly draws from three studies, i.e. RaUCH and TRINDADE (2002), Dunlevy (2006), and Peri and Requena (2010). Hence I'll focus on these three studies for the remainder of this literature review.

In an influential paper studying Chinese networks in international trade, RAUCH and TRINDADE (2002) suggested that the migrant effect on homogenous goods could be used to measure their trust effect. This is because homogenous goods, as opposed to differentiated goods, do not require specific searches. They thus identified the information channel by showing that the network effect on 
trade was statistically bigger for differentiated goods. Felbermayr and Toubal (2008) confirmed this result using data from OECD countries but Felbermayr et al. (2009) applied an updated empirical approach to the RAUCH and TRINDADE (2002) data and did not find the intuitive size ranking of network coefficients across differentiated and homogenous goods.

Dunlevy (2006) showed that the effect of immigrants on US exports was greater when the political climate in the partner country was more corrupt. $\mathrm{He}$ suggested this was because migrants were more important where it is more difficult to navigate the bureaucratic environment of the potential partner. What he did not draw attention to is whether migrant networks substitute for institutions through their trust or information effect.

More recently, Peri and Requena (2010) examined whether immigrants reduced the fixed costs of exporting, such as finding a business partner, or variable costs, such as transport costs and tariffs. Within the CHAney (2008) distorted gravity model, a reduction in fixed costs causes an increase in the number of exporting firms but does not affect the amount exported by each firm ${ }^{1}$. Using data from Spain, they find that immigrants significantly increase exports almost entirely via the extensive margin, as predicted by their impact on fixed entry costs. Yet, Coughuin et al. (2011) use an alternate definition of margins on US data and find an effect on the intensive margin only.

Hence the mechanisms at play remain blurry. In the next section I verify which of these findings hold for Switzerland and explain how they can be combined to shed more light on the mechanisms at play.

This is not the first paper in this literature to study the case of Switzerland. As mentioned above, both TAI (2009) and KANDOGAN (2009) have already done so. However, their contributions are very different from those of this paper. Both focus on the impact of immigrants on Swiss imports rather than exports. TAI (2009) studies the role of market structure, highlighting that the demand channel depends on the elasticity of substitution of goods within import categories. KANDOGAN's (2009) main result is that nostalgia trade is more important in the early years of immigration and when there are differences in languages.

1 This is because the optimal price and quantity produced by a firm does not depend on fixed trade costs in the model. However, a reduction in fixed costs reduces the productivity threshold for the exporting firm, hence affecting only the extensive margin. 


\section{Empirical Method and Data}

To estimate the protrade effect of migrants and disentangle the mechanisms at work, I use an enhanced log-linear version of the gravity model of trade (ANDERSON and van WINCOOP, 2003). I study the case of Switzerland as it provides highquality immigration data available from 1995 to 2009.

While most recent studies (e.g. Peri and Requena, 2010) focus on the variation within partners over time to identify the protrade effect of immigrants, I depart from the literature and average 14 years of data (1995-2009) to use only the variation across 174 trade partners ${ }^{2}$. There are two main reasons for this. The first is that the protrade effect could operate with an indeterminate lag, making yearly changes irrelevant. Indeed, as seen in the case of Croatia (Figure 1), the number of immigrants dropped suddenly around 2001 while exports stayed put. This indicates persistence in trade relationships. Hence, the levels of trade and migration, which reveal that Croatia remained a top-10 migration source, should provide more information about the power of migrant networks. The second reason is that co-integration of migration and exports, such as in Brazil's case (Figure 1), would reveal a significant migrant effect on exports within partner even if in reality the relationship only reflects two upward trends. Another reason is that corruption variation within a country is often meaningless over a fifteen-year period. For example, corruption has been fluctuating in Brazil but the country remained between the 50th and 60th most corrupt countries in the world. Another advantage of an averaged cross section is that yearly data noises are cancelled.

The main challenge with a cross section is that across countries, the relationship between exports and immigration (see Figure 2) may be driven by partnerspecific unobservables such as cultural fondness, or may go from trade to migration, rather than the other way round. This would lead to biased coefficients on migrants.

To control for the potential endogeneity and identify causality, I use an instrumental variable (IV) approach. To instrument for migrants in Switzerland, my first IV is the number of immigrants in France, which I get from the Global Origin Migrant Database (PARsons et al., 2007). The reason for which this should provide a good instrument is that France and Switzerland have a similar distribution of migrants' origins. However, migrants in France should not be able to help Swiss exports through any other channels than through links with migrants in Switzerland. Using a second IV allows me to increase the variance

2 I also estimate a partner fixed-effect model as a robustness check. 
Figure 1: The Examples of Brazil and Croatia

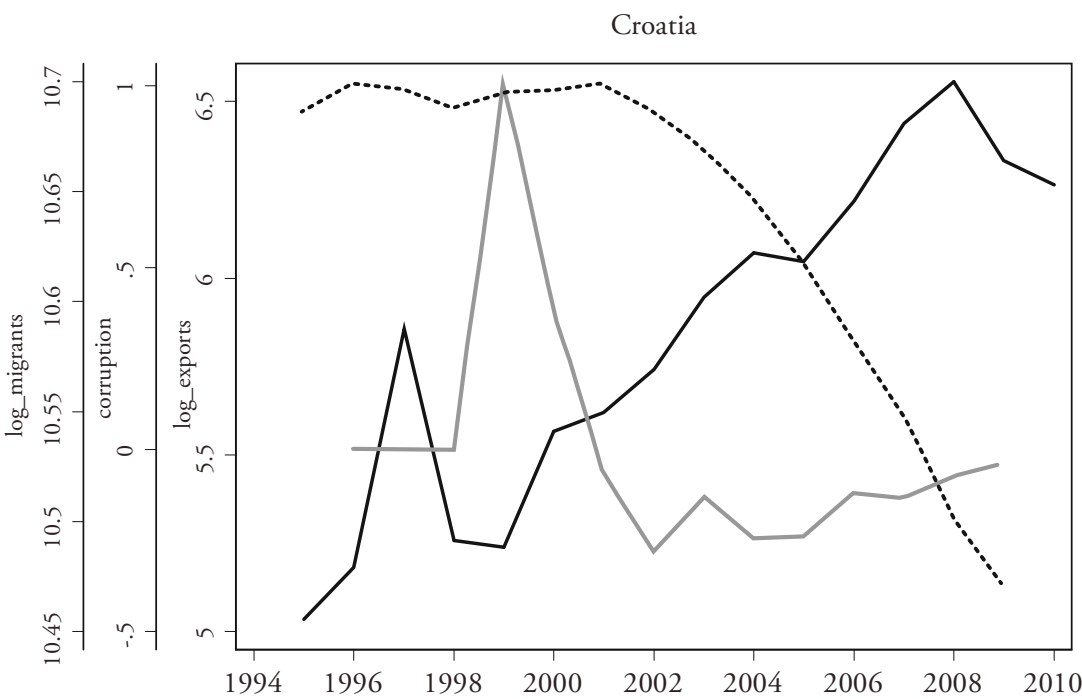

Brazil

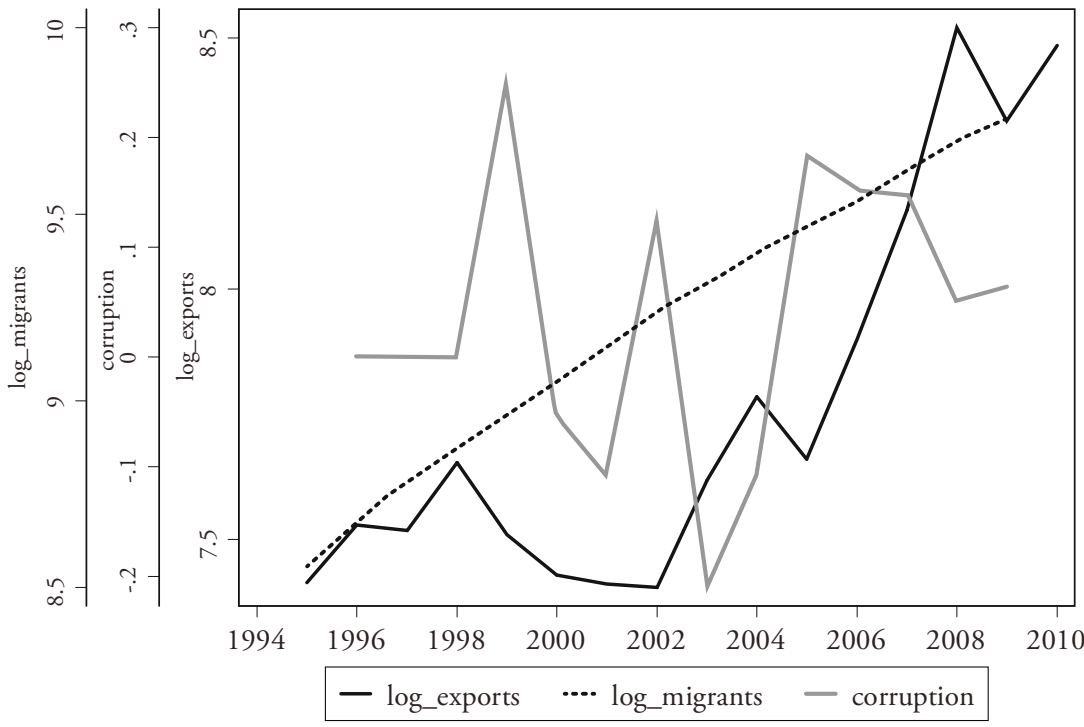


Figure 2: Swiss Export Values and Migrant Stocks - 1995-2009 Average

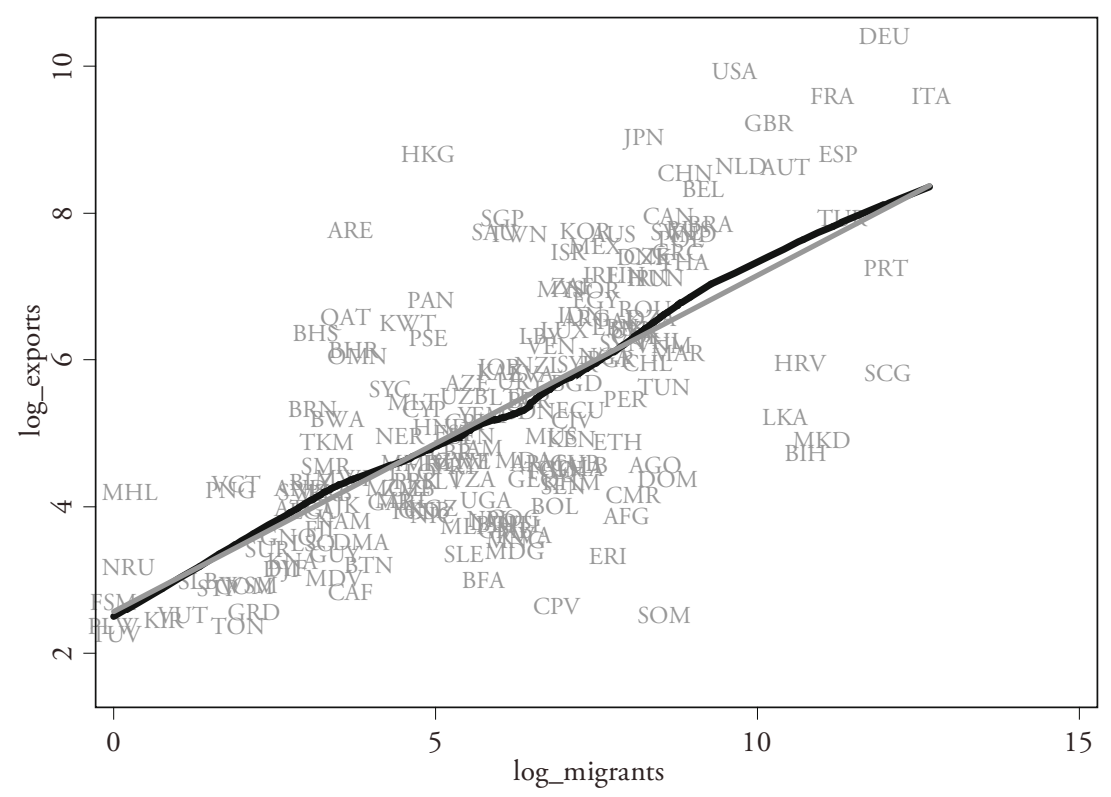

in predicted migration in my first stage regression and to test for overidentification, i.e. for the excludability of both instruments ${ }^{3}$. Hence, I also add Swiss visa restrictions as a second IV, using data from Neumayer (2006). The logic here is that, for reasons of immigration-control, Switzerland might use visa restrictions to intentionally deter individuals from some countries to immigrate. These restrictions to immigration should not affect Swiss exports through channels other than migration.

I combine four ideas from the previous literature to disentangle the mechanisms. I focus on exports to cut off the preference channel. To isolate the trust and information effects I decompose exports according to the RAUCH (1999) liberal classification into homogenous, reference-priced, and differentiated goods ${ }^{4}$. I

3 Peri and Requena (2010) used lagged migration stocks as an instrument for current migration. Yet, if the protrade effect operates with a lag, this instrument is not strictly excludable.

4 Using the conservative classification leads to very similar results. Another way to measure product differentiation is to use the import demand elasticities estimated by BroDA and WEINstein (2006), as in Peri and Requena (2010). 
interact the stock of migrants with the level of corruption in the origin country, as in Dunlevy (2006), to check whether migrant networks substitute for institutions through their trust or information channels ${ }^{5}$. I follow Peri and Requena (2010) and decompose exports into an extensive margin, defined as the number of SITC 4-digit product lines per partner, and an intensive margin, defined as the average value of exports ${ }^{6}$. This allows me to examine whether migrant networks decrease the fixed or variable costs of exporting.

The model to be estimated separately on homogenous, reference-priced, and differentiated goods can be written as follows:

EXPORTS $_{i}=\mathrm{f}\left(\begin{array}{c}\ln \text { MIGRANTS }_{i}, \ln \text { GDP }_{i}, \ln \text { GDPPC }_{i}, \ln \text { DISTANCE }_{i}, \\ \text { CORRUPTION }_{i}, \ln \left(\text { MIGRANTS }_{i}\right) \times \text { CORRUPTION }_{i}, Z_{i}\end{array}\right)$,

where

EXPORTS $_{i}$ is either the value of Swiss exports to country $i$ in current US dollars or the number of SITC 4-digit product lines. The data is from the UN Comtrade database,

MIGRANTS $_{i}$ is the stock of immigrants from country $i$ in Switzerland. Data is from the Swiss Federal Statistics Office,

$G D P_{i}$ is country $i$ 's Gross Domestic Product in current US dollars, taken from the World Bank's World Development Indicators (WDI),

$G D P P C_{i t}$ is country i's Gross Domestic Product per capita in current US dollars in, also taken from the WDI,

DISTANCE $E_{i}$ is the population-density-adjusted distance in km between Switzerland and country is principal city, as reported by CEPII,

CORRUPTION $_{i}$ is an indicator of country $i$ 's corruption from the Worldwide Governance Indicators (Kauffman et al. 2010) and it measures perceptions of the extent to which public power is exercised for private gain, including both petty and grand forms of corruption, as well as "capture" of the state by elites and private interests ${ }^{7}$,

$Z_{i t}$ includes other variables that characterise the relationship between country $i$ and Switzerland, such as a common language dummy (German, French

5 The interaction term is instrumented by the interaction of the IVs with the corruption variable.

6 One problem with this definition is that it could capture a selection of more expensive products rather than increased sales. I thus use the value of exports as a proxy for the intensive margin as a robustness check. As it captures both margins, it maximises the likelihood of finding an impact on the intensive margin. This definition confirms the results.

7 I use the negative of control-of-corruption. 
or Italian), a shared border dummy, and a preferential trade agreement (PTA) dummy provided by CEPII.

As Silva and Tenreyro (2006) showed that the Poisson pseudo maximum likelihood regression model was the most adequate for gravity models, (as it is more precise and consistent in the case of log-linearized models with heteroskedasticity), I use the instrumental variable Poisson model proposed by Mullahy (1997) and estimate standard errors bootstrapping ${ }^{8}$.

In the appendix I provide summary statistics (Table A1), a description of Switzerland's main export products (Table A2) as well as a Figure (A1) showing the relationship between the margins of trade across countries. I present the results in the next section.

\section{Empirical Findings}

Results are in Table 1. Both the weak-identification test and the over-identification test confirm the validity of my IVs. The Cragg-Donald F-statistic of 19.916 (above the Stock-Yogo critical values between 2 and 16) confirms the explanatory power of my IVs. According to the Hansen-J p-values I fail to reject the null hypothesis of excludability, suggesting the IVs do not explain exports through any other channel than migration.

Among the control variables, GDP and distance have the most explaining power, as predicted by gravity, even though distance does not affect the intensive margin. Common border and common language do not seem to boost exports, while trade agreements seem to have a negative impact on the extensive margin, quite surprisingly.

As for our variable of interest, at an average level of corruption, migrants cause an extension of exports, but not for differentiated products. However, the interaction of migrants with corruption is positive and significant only for differentiated goods and, though slightly less strongly, for reference-priced goods. This indicates that migrant networks substitute for formal institutions but not for homogenous goods.

Figure 3 allows for a careful interpretation of these results. It plots the marginal effects of migrants on trade at different levels of corruption as well as their

8 See Nichols (2007) for the implementation of the IV Poisson in stata. For the estimation the dependant variable is in levels, not logs. 
Table 1: IV-Poisson Gravity Estimates of the Protrade Effect of Migrants

\begin{tabular}{|c|c|c|c|c|c|c|}
\hline & \multicolumn{3}{|c|}{ Extensive margin } & \multicolumn{3}{|c|}{ Intensive margin } \\
\hline & 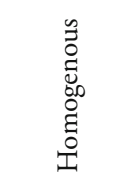 & 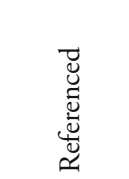 & 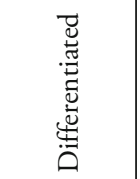 & 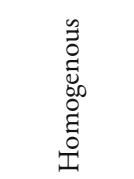 & 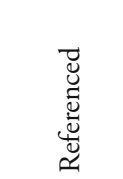 & 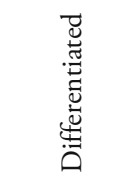 \\
\hline $\ln$ (migrants) & $\begin{array}{r}0.146^{* *} \\
(0.0615)\end{array}$ & $\begin{array}{c}0.126^{* *} \\
(0.0640)\end{array}$ & $\begin{array}{c}0.0650 \\
(0.0475)\end{array}$ & $\begin{array}{c}-0.103 \\
(0.217)\end{array}$ & $\begin{array}{c}0.585 \\
(0.374)\end{array}$ & $\begin{array}{c}-0.0535 \\
(0.0674)\end{array}$ \\
\hline corruption & $\begin{array}{l}-0.301 \\
(0.273)\end{array}$ & $\begin{array}{l}-0.530^{* *} \\
(0.254)\end{array}$ & $\begin{array}{l}-0.599 * * * \\
(0.177)\end{array}$ & $\begin{array}{c}0.351 \\
(1.280)\end{array}$ & $\begin{array}{c}0.950 \\
(0.686)\end{array}$ & $\begin{array}{c}0.0140 \\
(0.384)\end{array}$ \\
\hline $\begin{array}{l}\text { ln (migrants) } x \\
\text { corruption }\end{array}$ & $\begin{array}{r}0.00975 \\
(0.0406)\end{array}$ & $\begin{array}{c}0.0611^{*} \\
(0.0364)\end{array}$ & $\begin{array}{l}0.0765^{* * *} \\
(0.0246)\end{array}$ & $\begin{array}{l}-0.160 \\
(0.164)\end{array}$ & $\begin{array}{l}-0.169^{*} \\
(0.0891)\end{array}$ & $\begin{array}{c}-0.0192 \\
(0.0493)\end{array}$ \\
\hline $\ln (\mathrm{GDP})$ & $\begin{array}{c}0.310^{* * *} \\
(0.0603)\end{array}$ & $\begin{array}{c}0.373^{* * *} \\
(0.0629)\end{array}$ & $\begin{array}{c}0.313^{* * *} \\
(0.0467)\end{array}$ & $\begin{array}{l}0.475^{* * *} \\
(0.177)\end{array}$ & $\begin{array}{c}0.0324 \\
(0.346)\end{array}$ & $\begin{array}{c}0.619^{* * *} \\
(0.0654)\end{array}$ \\
\hline ln (GDP per capita) & $\begin{array}{c}0.108^{*} \\
(0.0607)\end{array}$ & $\begin{array}{c}0.0754 \\
(0.0673)\end{array}$ & $\begin{array}{c}0.00409 \\
(0.0493)\end{array}$ & $\begin{array}{l}-0.000921 \\
(0.340)\end{array}$ & $\begin{array}{c}0.394 \\
(0.300)\end{array}$ & $\begin{array}{c}0.171^{*} \\
(0.0976)\end{array}$ \\
\hline $\ln$ (distance) & $\begin{array}{r}-1.286^{*} \\
(0.722)\end{array}$ & $\begin{array}{l}-2.207^{* * *} \\
(0.675)\end{array}$ & $\begin{array}{l}-2.612^{* * *} \\
(0.515)\end{array}$ & $\begin{array}{c}1.089 \\
(3.276)\end{array}$ & $\begin{array}{c}1.660 \\
(3.186)\end{array}$ & $\begin{array}{c}-1.176 \\
(0.938)\end{array}$ \\
\hline Border & $\begin{array}{c}-0.157 \\
(0.272)\end{array}$ & $\begin{array}{c}-0.314 \\
(0.416)\end{array}$ & $\begin{array}{c}-0.368 \\
(0.294)\end{array}$ & $\begin{array}{c}0.0632 \\
(1.306)\end{array}$ & $\begin{array}{l}0.00159 \\
(0.867)\end{array}$ & $\begin{array}{l}0.973^{* * *} \\
(0.283)\end{array}$ \\
\hline common language & $\begin{array}{c}0.0467 \\
(0.108)\end{array}$ & $\begin{array}{c}-0.192^{*} \\
(0.116)\end{array}$ & $\begin{array}{c}-0.0514 \\
(0.0874)\end{array}$ & $\begin{array}{c}0.952 \\
(0.587)\end{array}$ & $\begin{array}{l}-0.273 \\
(0.547)\end{array}$ & $\begin{array}{c}-0.0569 \\
(0.235)\end{array}$ \\
\hline PTA & $\begin{array}{c}-0.0628 \\
(0.156)\end{array}$ & $\begin{array}{l}-0.409^{* *} \\
(0.159)\end{array}$ & $\begin{array}{c}-0.341^{* * *} \\
(0.129)\end{array}$ & $\begin{array}{l}-0.224 \\
(1.143)\end{array}$ & $\begin{array}{c}-0.683 \\
(0.726)\end{array}$ & $\begin{array}{c}-0.0584 \\
(0.257)\end{array}$ \\
\hline Constant & $\begin{array}{l}-4.556^{* * *} \\
(1.298)\end{array}$ & $\begin{array}{c}-1.783 \\
(1.303)\end{array}$ & $\begin{array}{l}2.968^{* * *} \\
(1.071)\end{array}$ & $\begin{array}{l}-7.415 \\
(7.653)\end{array}$ & $\begin{array}{l}-5.819 \\
(5.125)\end{array}$ & $\begin{array}{l}-7.294^{* * *} \\
(2.195)\end{array}$ \\
\hline Hansen J p-value & 0.4121 & 0.1448 & 0.8046 & 0.5698 & 0.8764 & 0.3365 \\
\hline Cragg-Donald F stat & 19.916 & 19.916 & 19.916 & 19.916 & 19.916 & 19.916 \\
\hline $\mathrm{N}$ & 174 & 174 & 174 & 174 & 174 & 174 \\
\hline
\end{tabular}

Note: Coefficients obtained using the GMM estimator of an IV Poisson regression (Mullahy 1997). Bootstrapped (200 replications) standard errors are in parentheses. ${ }^{* *},{ }^{* *}$ and ${ }^{*}$ denote statistical significance at the $1 \%, 5 \%$ and $10 \%$ levels, respectively. Excluded instruments are ln (migrants in France) and a visa restrictions dummy, as well as their interaction with control of corruption. 


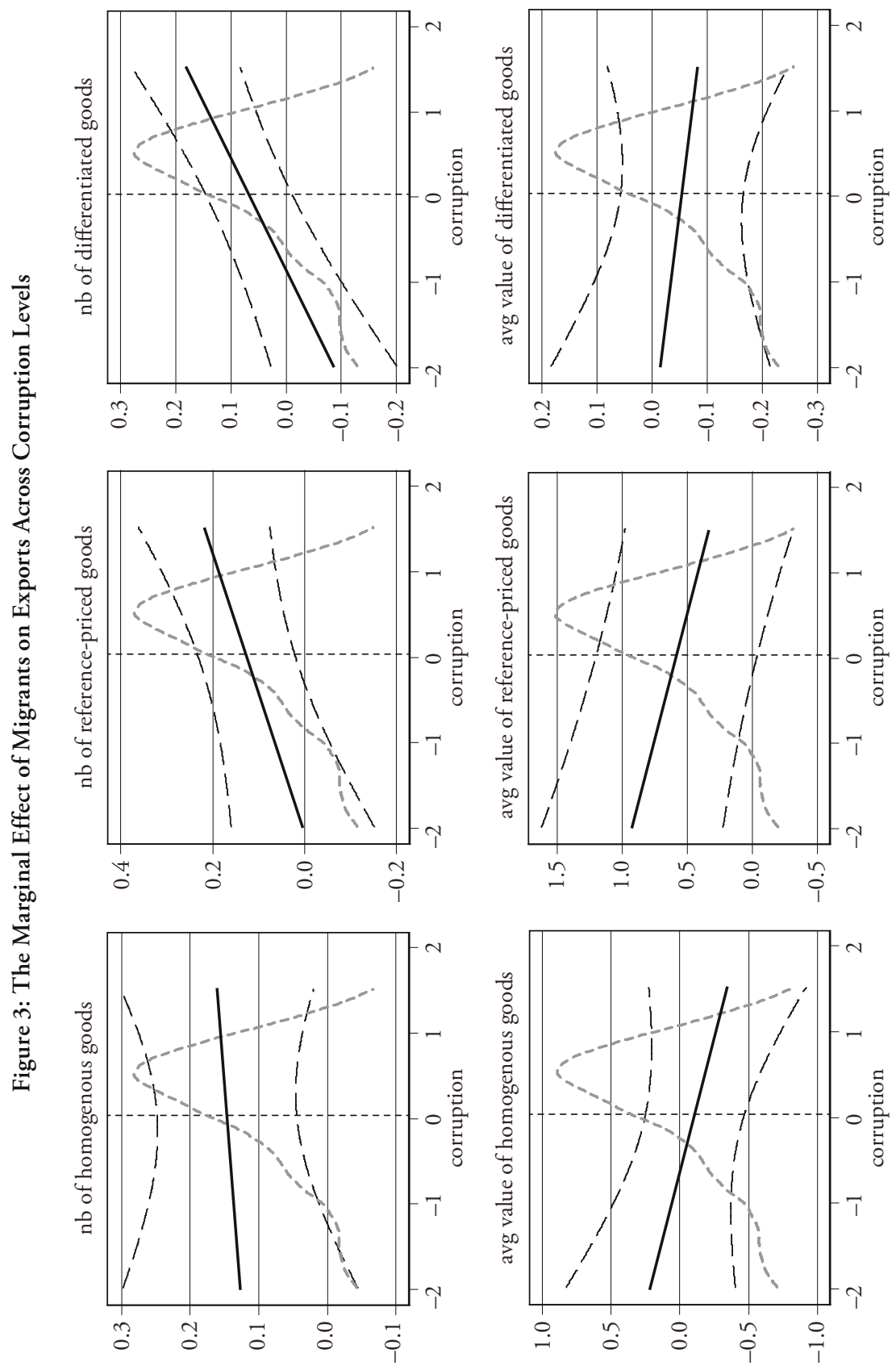


confidence intervals ${ }^{9}$. It superposes the density estimate of the corruption variable to indicate its distribution among trade partners. One can hence visualise for which proportion of countries the effect is significant.

While there is no statistical difference between the effects of migrants on the extensive margin of differentiated and homogenous goods, the effect more than doubles on differentiated exports from countries with average to the highest corruption such as Chad or Belarus. Furthermore, the marginal effect of migrants on the extensive margin is insignificant for those countries that have low levels of corruption, such as New Zealand or Sweden.

As seen in the lower panels, the marginal effect of migrants on the intensive margin of homogenous and differentiated products is insignificant at all levels of corruption. This confirms the results of Peri and Requena (2010), namely that migrants decrease the fixed cost of exporting, as the impact of migrants is positive and significant only on the extensive margin ${ }^{10}$.

One interpretation of these findings is that migrants substitute for institutions through their information effect, and not a contract-enforcement effect. Another is that homogenous goods are not only less search- but also less trustintensive, as suggested by Guiso, SAPIENZA and Zingales (2009) but contrasting with RAUCH and TrindADE's (2002) assertion. This would mean that the Rauch classification is not fully appropriate to disentangle the trust and information channels. Either way, this involves that migrants promote homogenous exports through a mechanism formal institutions cannot substitute for.

\section{Robustness Checks}

As some may dispute the applicability of the IV Poisson and the cross section approach, I verify if my results hold when applying various estimators. I provide in Table 2 the coefficients on migrants and its interaction with corruption obtained using OLS, IV-2SLS, Poisson and negative binomial maximum likelihood, and a partner fixed-effect Poisson model where corruption enters as its average across time so as to capture only the cross-country variation in corruption.

9 The standard error of interest is:

$$
\sqrt{\operatorname{var}\left(\beta_{\text {migrants }}\right)+\text { corruption }^{2} \times \operatorname{var}\left(\beta_{\text {interaction }}\right)+2 \times(\text { corruption }) \times \operatorname{cov}\left(\beta_{\text {migrants }} \beta_{\text {interaction }}\right)} .
$$

10 For reference-priced goods however I find a positive effect for non-corrupt countries. This could be explained by a selection of expensive chemicals sold to its European neighbours. 
All these estimators confirm the significance of migrants and its interaction with corruption on the extensive margin of differentiated goods. At an average level of corruption, the effect of migrants on exports varies between 0.065 and 0.105 across countries and is estimated at 0.065 within countries. The withincountry estimate is very close to the estimator obtained across countries using the IV Poisson. The IV-Poisson appears to be the most conservative estimator as other estimators give more significance to the effect on homogenous and reference-priced goods. As for the intensive margin, results are not consistent across estimators.

Table 2: Robustness to Various Estimators

\begin{tabular}{|c|c|c|c|c|c|c|}
\hline & \multicolumn{3}{|c|}{ Extensive margin } & \multicolumn{3}{|c|}{ Intensive margin } \\
\hline & 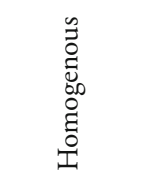 & 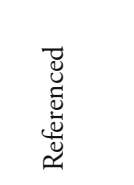 & 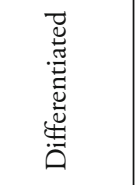 & 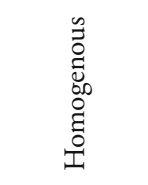 & 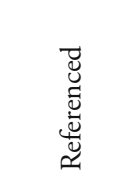 & 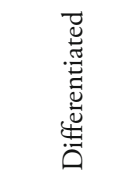 \\
\hline IV-Poisson & $\begin{array}{l}0.146^{* *} \\
0.00975\end{array}$ & $\begin{array}{l}0.126^{* *} \\
0.0611^{*}\end{array}$ & $\begin{array}{l}0.0650 \\
0.0765^{* * *}\end{array}$ & $\begin{array}{l}-0.103 \\
-0.160\end{array}$ & $\begin{array}{c}0.585 \\
-0.169^{*}\end{array}$ & $\begin{array}{l}-0.0535 \\
-0.0192\end{array}$ \\
\hline OLS & $\begin{array}{c}0.0609^{* * *} \\
-0.00377\end{array}$ & $\begin{array}{l}0.126^{* * *} \\
0.0713^{* * *}\end{array}$ & $\begin{array}{l}0.105^{* * *} \\
0.0857^{* * *}\end{array}$ & $\begin{array}{l}-0.0108 \\
-0.0642\end{array}$ & $\begin{array}{c}0.0760 \\
-0.0961^{*}\end{array}$ & $\begin{array}{r}-0.0640 \\
0.0173\end{array}$ \\
\hline IV-2SLS & $\begin{array}{c}0.112^{* * *} \\
-0.0115\end{array}$ & $\begin{array}{l}0.114^{* *} \\
0.0549^{*}\end{array}$ & $\begin{array}{l}0.0759 \\
0.0819^{* * *}\end{array}$ & $\begin{array}{c}0.177 \\
-0.157^{*}\end{array}$ & $\begin{array}{c}0.174 \\
-0.151^{* * *}\end{array}$ & $\begin{array}{l}-0.0546 \\
-0.00212\end{array}$ \\
\hline Poisson & $\begin{array}{l}0.0621^{* * *} \\
0.0908^{* * *}\end{array}$ & $\begin{array}{l}0.101^{* * *} \\
0.108^{* * *}\end{array}$ & $\begin{array}{l}0.0771^{* * *} \\
0.0858^{* * *}\end{array}$ & $\begin{array}{c}-0.425^{* *} \\
0.179\end{array}$ & $\begin{array}{c}0.126^{* *} \\
-0.0161\end{array}$ & $\begin{array}{r}-0.0767 \\
0.00829\end{array}$ \\
\hline $\begin{array}{l}\text { Negative } \\
\text { binomial }\end{array}$ & $\begin{array}{l}0.0697^{* * *} \\
0.0882^{* * *}\end{array}$ & $\begin{array}{l}0.130^{* * *} \\
0.0953^{* * *}\end{array}$ & $\begin{array}{l}0.101^{* * *} \\
0.0826^{* * *}\end{array}$ & $\begin{array}{r}-0.0773 \\
0.0492\end{array}$ & $\begin{array}{r}0.0454 \\
-0.117^{*}\end{array}$ & $\begin{array}{r}-0.0479 \\
0.0229\end{array}$ \\
\hline $\begin{array}{l}\text { Poisson } \\
\text { fixed effects }\end{array}$ & $\begin{array}{l}0.0289 \\
0.00582\end{array}$ & $\begin{array}{l}0.0395^{*} \\
0.00768^{* *}\end{array}$ & $\begin{array}{l}0.0653^{*} \\
0.00880^{* *}\end{array}$ & $\begin{array}{l}-0.164^{* *} \\
-0.000956\end{array}$ & $\begin{array}{l}-0.0514 \\
-0.0135\end{array}$ & $\begin{array}{c}-0.0281 \\
0.000166\end{array}$ \\
\hline
\end{tabular}

Note: For each estimator, the first row gives the coefficient on log_migrants while the second row gives the one on log_migrants $\mathrm{x}$ corruption. ${ }^{* * *},{ }^{* *}$ and ${ }^{*}$ denote statistical significance at the $1 \%$, $5 \%$ and $10 \%$ levels, respectively. For the IV-Poisson standard errors are bootstrapped (200 replications), for OLS, IV-2SLS, Poisson, Negative binomial, they are robust to heteroskedastcity, and for Poisson fixed effects they are partner clustered. 
The substitution effect between migrants and institutions is also robust to the use of alternate measures of institutions, i.e. rule-of-law and regulatory quality from the World Bank's World Governance Indicators ${ }^{11}$ (KAUfFMAN et al., 2010), an indicator from the World Economic Forum which measures business executives' perceptions of their country's efficiency of customs procedures ${ }^{12}$, as well as the World Bank's Doing Business' ranking of contract enforcement which measure the efficiency of the judicial system in resolving a commercial dispute ${ }^{13}$. See Table 3 and Figure 4.

Table 3: Robustness to Various Institutional Indicators

\begin{tabular}{|c|c|c|c|c|c|c|}
\hline & \multicolumn{3}{|c|}{ Extensive margin } & \multicolumn{3}{|c|}{ Intensive margin } \\
\hline & 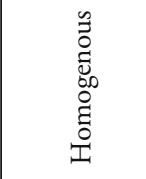 & 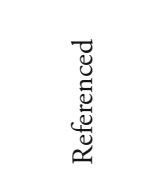 & 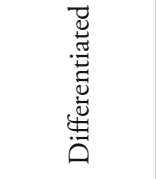 & 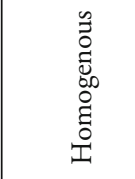 & 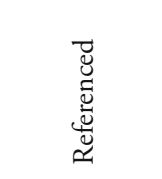 & 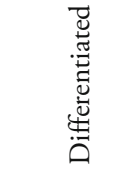 \\
\hline $\begin{array}{l}\text { Regulatory } \\
\text { quality }\end{array}$ & $\begin{array}{l}0.148^{* * *} \\
0.00827\end{array}$ & $\begin{array}{r}0.130^{* *} \\
-0.0701^{*}\end{array}$ & $\begin{array}{c}0.0728^{*} \\
-0.113^{* * *}\end{array}$ & $\begin{array}{r}-0.298 \\
0.216\end{array}$ & $\begin{array}{l}0.689^{*} \\
0.211^{* *}\end{array}$ & $\begin{array}{r}-0.0545 \\
0.0687\end{array}$ \\
\hline Rule of law & $\begin{array}{c}0.143^{* *} \\
-0.00606\end{array}$ & $\begin{array}{c}0.126^{* *} \\
-0.0810^{*}\end{array}$ & $\begin{array}{c}0.0723 \\
-0.101^{\text {*** }}\end{array}$ & $\begin{array}{r}-0.232 \\
0.214\end{array}$ & $\begin{array}{l}0.637 \\
0.119\end{array}$ & $\begin{array}{c}-0.0603 \\
0.00914\end{array}$ \\
\hline Customs & $\begin{array}{c}0.276^{* *} \\
-0.0314\end{array}$ & $\begin{array}{c}0.436^{* * *} \\
-0.0710^{* *}\end{array}$ & $\begin{array}{c}0.425^{* * *} \\
-0.0794^{* * *}\end{array}$ & $\begin{array}{c}0.311 \\
-0.0528\end{array}$ & $\begin{array}{l}0.302 \\
0.0814\end{array}$ & $\begin{array}{c}0.203 \\
-0.0631^{*}\end{array}$ \\
\hline $\begin{array}{l}\text { Contract } \\
\text { enforcement }\end{array}$ & $\begin{array}{l}0.129^{*} \\
0.000492\end{array}$ & $\begin{array}{l}0.0361 \\
0.00132^{* * *}\end{array}$ & $\begin{array}{l}-0.0135 \\
0.00127^{* * *}\end{array}$ & $\begin{array}{c}0.0648 \\
-0.00203\end{array}$ & $\begin{array}{c}0.919^{* *} \\
-0.00303^{* * *}\end{array}$ & $\begin{array}{l}-0.0290 \\
-0.000496\end{array}$ \\
\hline
\end{tabular}

Note: IV Poisson regressions. For each estimator, the first row gives the coefficient on log_migrants while the second row gives the one on its interaction with the institutional variable.

11 Rule of law captures the extent to which agents have confidence in and abide by the rules of society, and in particular the quality of contract enforcement, property rights, the police, and the courts, as well as the likelihood of crime and violence; regulatory quality captures the ability of the government to formulate and implement sound policies and regulations that permit and promote private sector development.

12 This indicator is available in the World Development indicators database.

13 As this indicator is not available for the years covered but only starting in 2004, this should be only indicative. 


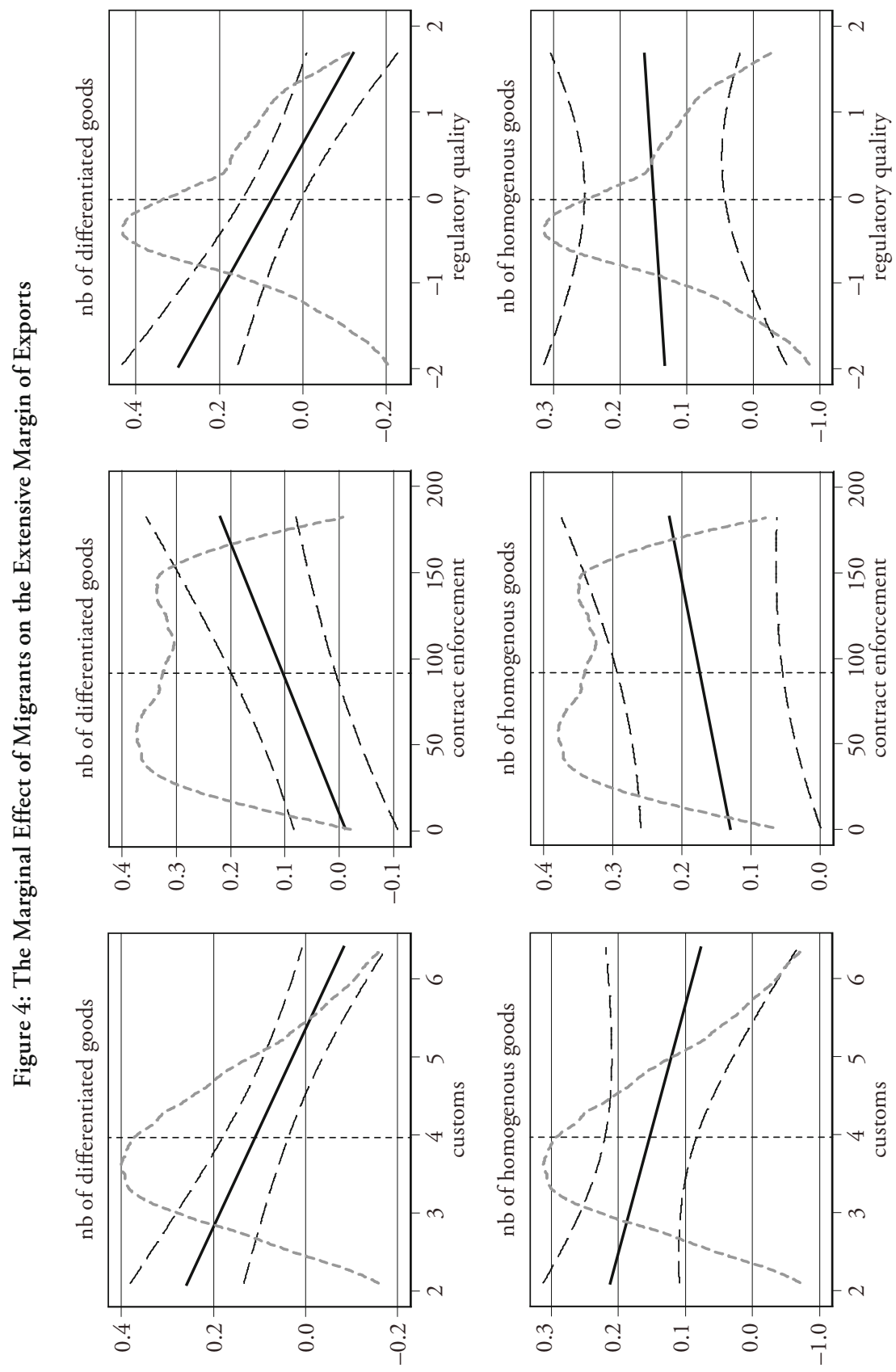


For another robustness check I estimate the model adding real passport costs as a third predictor of emigration in the first stage, as JAVORCIK et al. (2011). McKenzie (2007) showed that high passport costs are associated with lower levels of outward migration and tend to be correlated with other emigration barriers imposed by countries. Using this IV reduces the sample to 120 observations but confirms the results, though it suggests a substitution effect for homogenous goods as well (Table 4).

Table 4: Robustness to an Additional IV: Passport Costs

\begin{tabular}{|c|c|c|c|c|c|c|}
\hline & \multicolumn{3}{|c|}{ Extensive margin } & \multicolumn{3}{|c|}{ Intensive margin } \\
\hline & 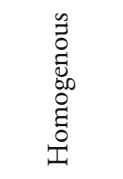 & 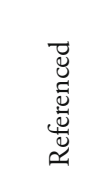 & 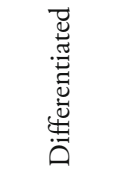 & 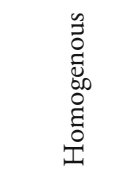 & 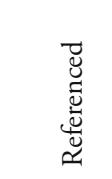 & 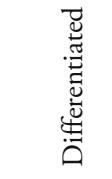 \\
\hline $2 \mathrm{IVs}$ & $\begin{array}{l}0.146^{* *} \\
0.00975\end{array}$ & $\begin{array}{l}0.126^{* *} \\
0.0611^{*}\end{array}$ & $\begin{array}{l}0.0650 \\
0.0765^{* * *}\end{array}$ & $\begin{array}{l}-0.103 \\
-0.160\end{array}$ & $\begin{array}{c}0.585 \\
-0.169^{*}\end{array}$ & $\begin{array}{l}-0.0535 \\
-0.0192\end{array}$ \\
\hline $3 \mathrm{IVs}$ & $\begin{array}{l}0.108^{* *} \\
0.0839^{* *}\end{array}$ & $\begin{array}{l}0.134^{* *} \\
0.107^{* *}\end{array}$ & $\begin{array}{l}0.0975^{* *} \\
0.118^{* * *}\end{array}$ & $\begin{array}{r}0.0124 \\
-0.0370\end{array}$ & $\begin{array}{r}0.285 \\
-0.238\end{array}$ & $\begin{array}{r}-0.0364 \\
0.0377\end{array}$ \\
\hline
\end{tabular}

Note: Coefficients obtained using the GMM estimator of an IV Poisson regression (Mullahy 1997). Bootstrapped (200 replications) standard errors were estimated. ${ }^{* * *},{ }^{* *}$ and ${ }^{*}$ denote statistical significance at the $1 \%, 5 \%$ and $10 \%$ levels, respectively. For each estimator, the first row gives the coefficient on log_migrants while the second row gives the one on log_migrants x corrupt. Excluded instruments in 2 IVs are ln (migrants in France) and a visa restrictions dummy, as well as their interaction with control of corruption. Passport costs / GDP per capita, as well as its interaction with corruption, are added as a third IV in 3 IVs.

Finally I run a bunch of other robustness checks on the intensive-vs-extensive result to examine whether migrants really do help reduce fixed rather than variable costs. Peri and Requena (2010) write that the presence of immigrants may reduce the information costs and the costs of setting up business and that immigrants themselves may become exporters and face much lower set-up costs in their countries of origin. This is quite intuitive and not so hard to believe. But they add that on the other hand, variable costs are usually associated with transport and tariff-costs which are less susceptible of being affected by immigrants. This is not as obvious. If migrants know cheap distribution channels and pay cheap bribes rather than high tariffs, they should affect variables costs as well. 
To dig deeper in this analysis I first I check if migrants increase the intensive margin when tariffs are high or when distance is long. I run the model described above but interacting migrants with distance or the partner's average applied tariff rather than corruption. I still find an insignificant impact of migrants on all types of export average values. The interaction between migrants and distance is not significant and neither is the one with average tariff (see Figure 5). This suggests migrants do not reduce variable costs associated tariffs or with distance, such as transport costs.

As the definition of the intensive margin of Peri and Requena (2010) might be inadequate, I check if the results hold when using the total value of exports rather than the average value. As the total value of exports captures both margins, it maximises the likelihood of finding an impact. But even using this definition, I find that migrants do not increase the total export value of homogenous and differentiated goods (see Figure 6).

Added-variable plots, obtained after OLS regressions, illustrate this pattern clearly. When controlling for everything else, migrants indeed do not predict the average value of exports but the number of exported products (Figure 7). This holds for all types of goods.

I also run the regressions including Swiss emigrants in partner countries using data from the Global Migrant Origin Database to verify whether they also play a role in Swiss exports. I find no significant effect of Swiss migrants, possibly because there is no demand effect or because partner countries do not need trust nor information to import from Switzerland. Nevertheless, the inclusion of this variable does not affect previous results (results not shown). 

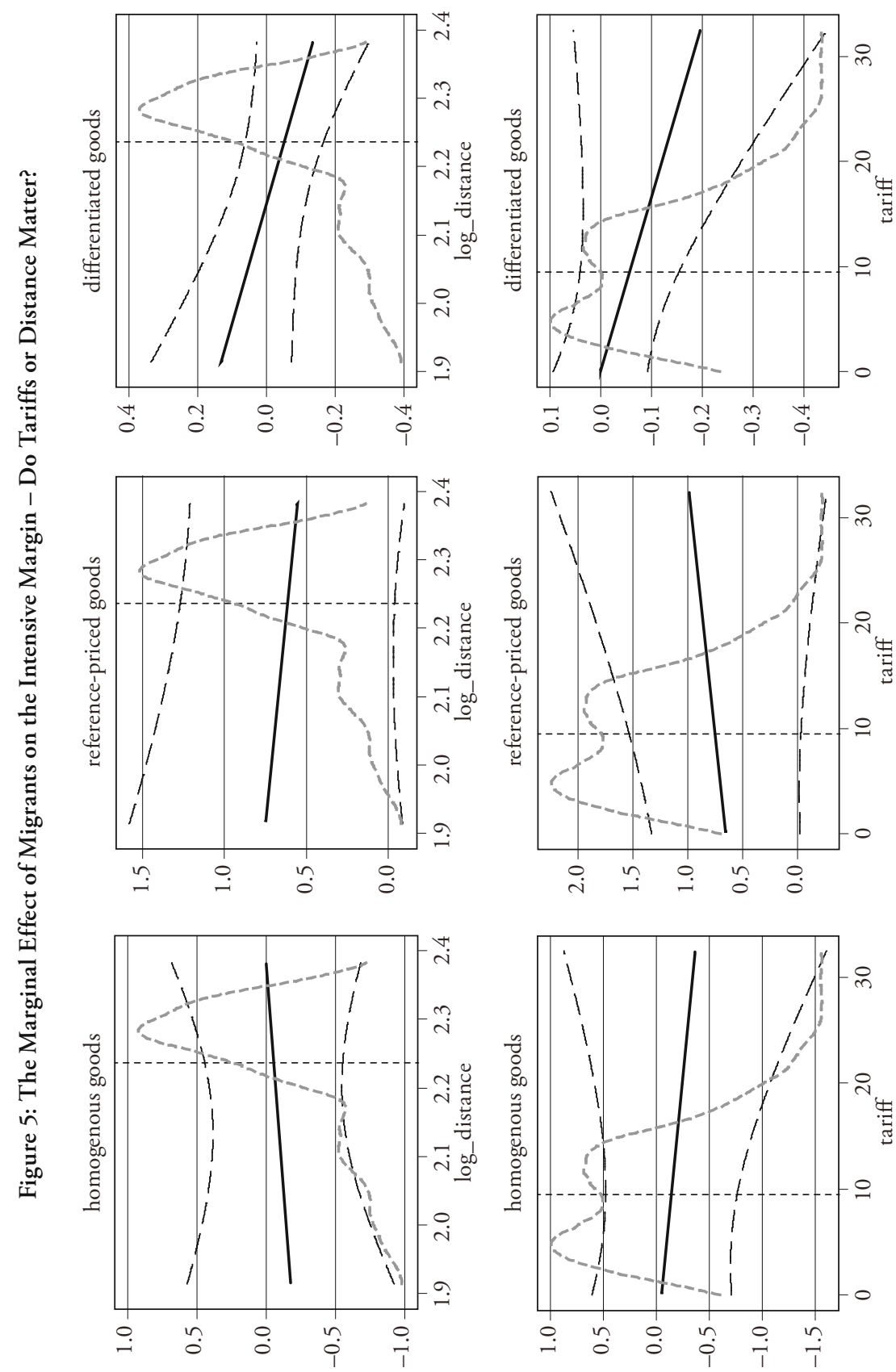


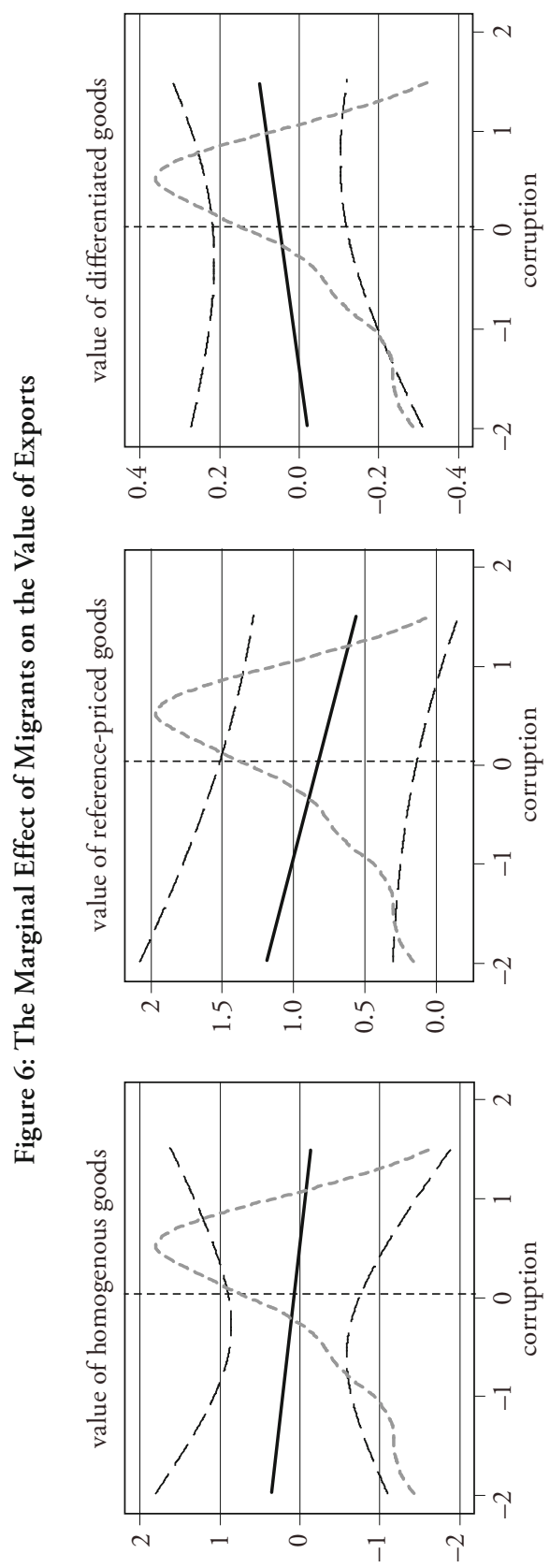



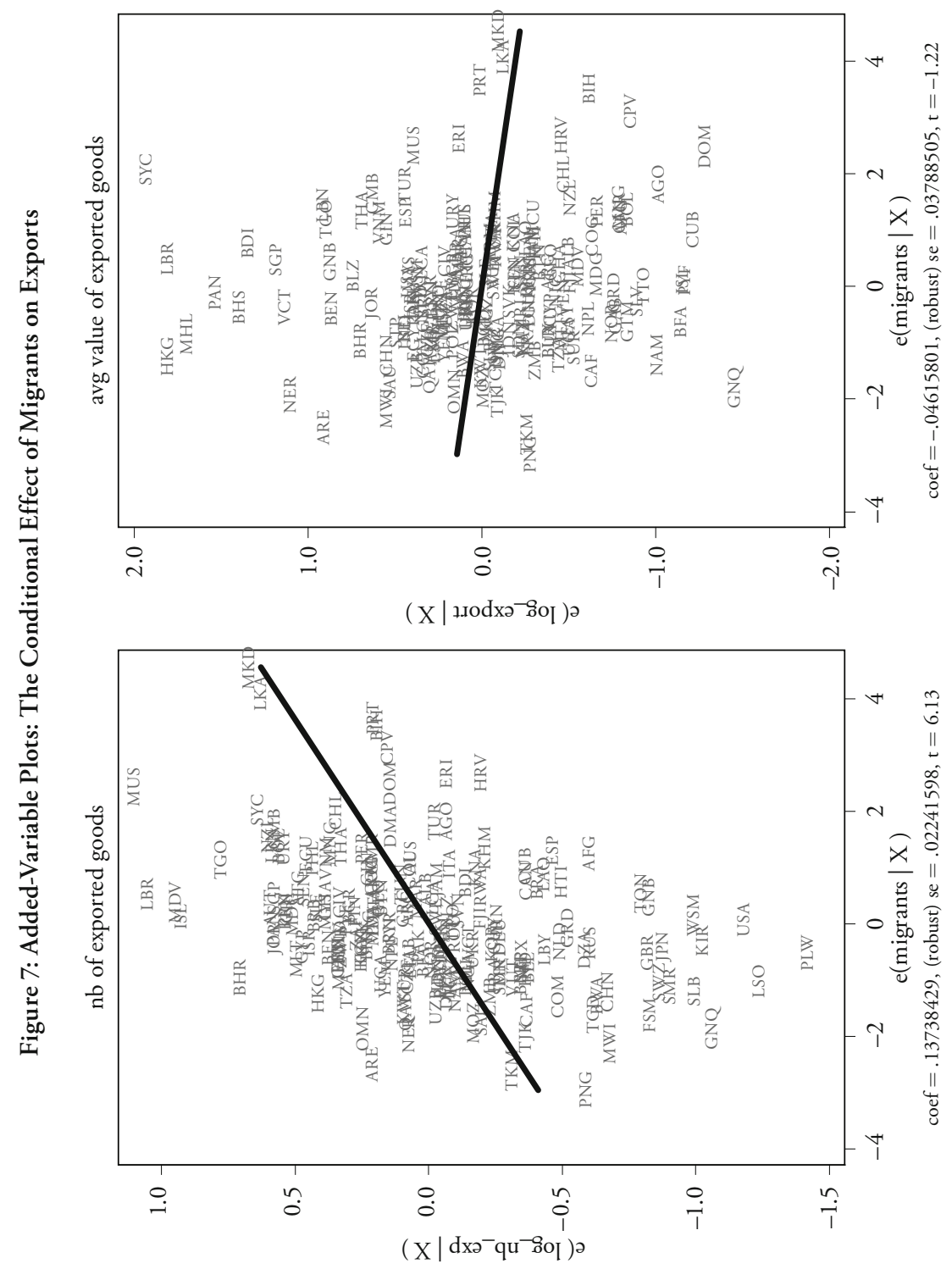


\section{Conclusion}

This paper presents robust evidence of a causal effect of migrants on of all types of exports. Using the immigrant stock in France as well as Swiss visa restrictions as instruments for the immigrant stock in Switzerland, I identified a robust protrade effect that takes place entirely on the extensive margin, i.e. on the number of exported products rather than the value of exports. This suggests migrant networks reduce beachhead costs. I also provide further evidence that migrant networks can substitute for formal institutions, but not so for homogenous goods. Taken together, this suggests either that differentiated goods are not only more search- but also more trust-intensive, or that migrants substitute for institutions by providing information, not by enforcing contracts. Either way, migrants appear to promote homogenous exports through a mechanism formal institutions cannot substitute for. It remains to be verified whether in a world of perfect information and rule of law, migrant networks would still play a role in promoting trade through channels this paper has failed to consider. This promises for exciting future research. In terms of policy implications, this paper makes an ever stronger case for immigration which benefits continue to be underappreciated. 


\section{Appendix}

Table A1: Summary Statistics (Averaged across 1995-2009)

\begin{tabular}{|c|c|c|c|c|c|}
\hline Variable & Obs & Mean & Std. Dev. & Min & Max \\
\hline migrants & 194 & 8049.87 & 32240.65 & 0 & 320289.30 \\
\hline corruption & 200 & 0.03 & 0.83 & -1.98 & 1.52 \\
\hline GDP & 190 & $2.1 \mathrm{E}+11$ & $9.1 \mathrm{E}+11$ & $8.5 \mathrm{E}+07$ & $1.1 \mathrm{E}+13$ \\
\hline GDP per capita & 190 & 9106.17 & 13421.72 & 122.31 & 76242.71 \\
\hline distance & 221 & 6631.25 & 4320.85 & 322.15 & 18635.84 \\
\hline border & 221 & 0.02 & 0.13 & 0 & 1 \\
\hline common language & 221 & 0.20 & 0.40 & 0 & 1 \\
\hline PTA & 221 & 0.13 & 0.32 & 0 & 1 \\
\hline migrants in France & 197 & 31236.90 & 127635.6 & 0 & 1333587 \\
\hline visa restrictions & 188 & 0.62 & 0.49 & 0 & 1 \\
\hline$\cong$ Differentiated & 242 & 1053.65 & 3581.543 & 0 & 40165.09 \\
\hline is 质 Reference-priced & 242 & 670.40 & 2609.475 & 0 & 29360.86 \\
\hline \& Homogenous & 242 & 709.88 & 2532.03 & 0 & 22044.47 \\
\hline \multirow{3}{*}{ 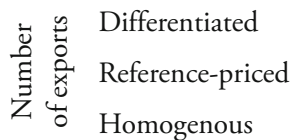 } & 242 & 139.37 & 125.76 & 0 & 441.77 \\
\hline & 242 & 38.64 & 45.92 & 0 & 193.64 \\
\hline & 242 & 8.77 & 14.51 & 0 & 91.49 \\
\hline
\end{tabular}


Table A2: Main Swiss Exports 1996-2005 (Share of Total Exports)

\begin{tabular}{|c|c|}
\hline \multicolumn{2}{|l|}{ Homogenous } \\
\hline Platinum: Unwrought or in powder & 1.77 \\
\hline Palladium: Unwrought or in powder & 1.43 \\
\hline Platinum: Other & 0.23 \\
\hline Non-monetary Gold: Semi-manufactured & 0.19 \\
\hline Palladium: Other & 0.11 \\
\hline Tobacco, partly or wholly stemmed & 0.08 \\
\hline Ferrous waste and scrap & 0.07 \\
\hline Semi-manufactured Silver & 0.04 \\
\hline Aluminium alloys & 0.03 \\
\hline Waste and scrap of gold & 0.03 \\
\hline \multicolumn{2}{|l|}{ Reference-priced } \\
\hline Electrical energy & 3.87 \\
\hline Non-industrial Diamonds: Other & 1.48 \\
\hline Non-industrial Diamonds: Unworked or simply sawn & 0.71 \\
\hline Other cheese & 0.64 \\
\hline Lactones: Other & 0.57 \\
\hline Cigarettes containing tobacco & 0.52 \\
\hline Epoxide resins & 0.47 \\
\hline Rubies, sapphires and emeralds & 0.42 \\
\hline Sulphonamides & 0.41 \\
\hline Amino-alcohol-phenols, amino-acid-phenols & 0.35 \\
\hline \multicolumn{2}{|l|}{ Differentiated } \\
\hline Antisera and other blood fractions & 4.57 \\
\hline Wrist-watches, other & 1.69 \\
\hline Pacemakers for stimulating heart & 1.13 \\
\hline Paintings, drawings and pastels & 1.12 \\
\hline Medicaments Containing other antibiotics & 1.11 \\
\hline Wrist-watches, electrically operated & 0.99 \\
\hline Jewellery of precious metal & 0.94 \\
\hline Parts for machining Centres, Lathes or Planing Machines & 0.73 \\
\hline Artificial joints and other orthopaedic appliances & 0.70 \\
\hline Other machines and mechanical appliances & 0.69 \\
\hline
\end{tabular}




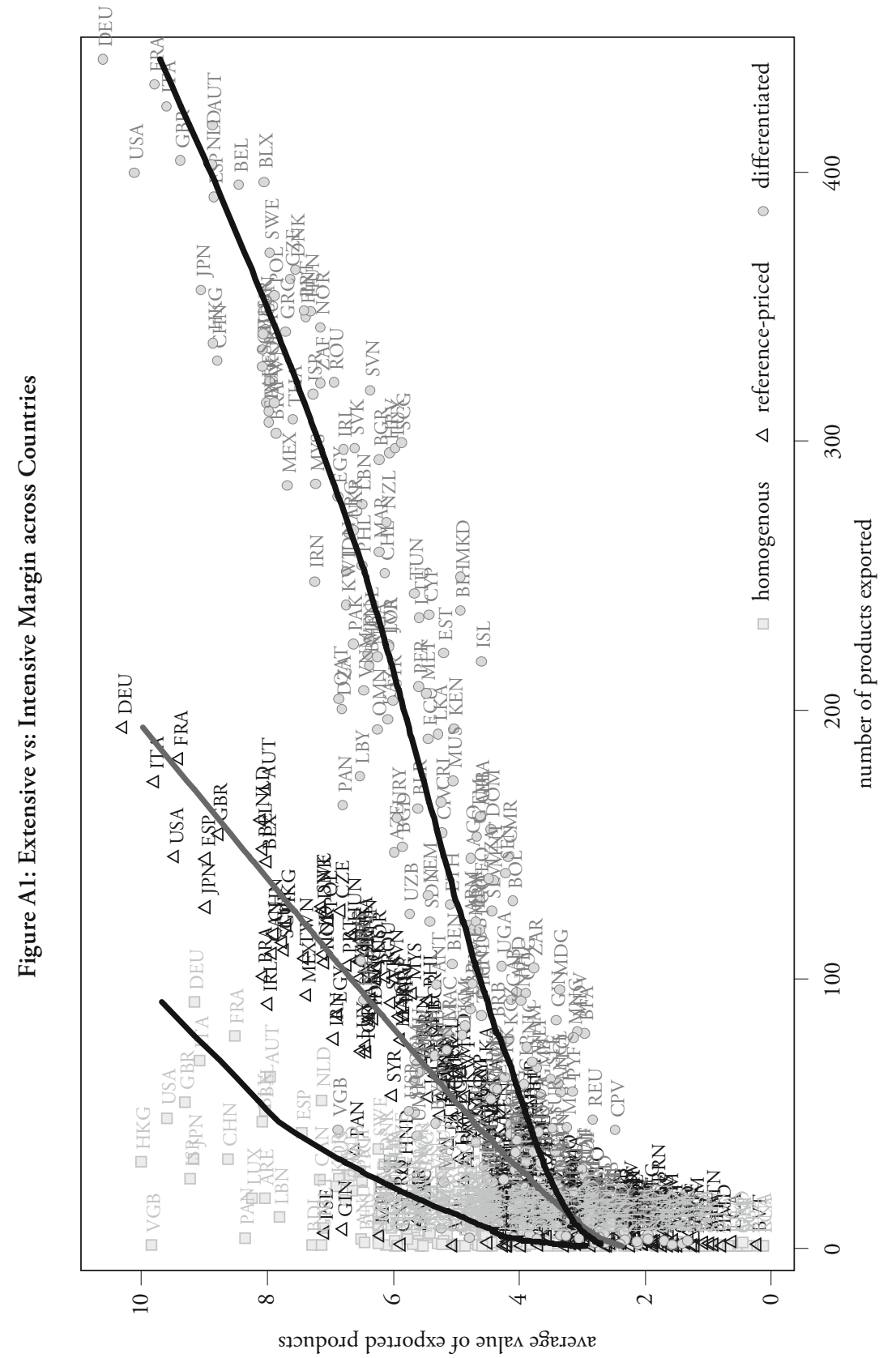

Swiss Journal of Economics and Statistics, 2012, Vol. 148 (3) 


\section{References}

Anderson, James E., and Douglas S. J. Marcouiller (2002), "Insecurity and the Pattern of Trade: An Empirical Investigation", Review of Economics and Statistics, 84: pp. 342-352.

Anderson, James E., and Eric van Wincoop (2003), "Gravity with Gravitas: A Solution to the Border Puzzle", American Economic Review, American Economic Association, 93(1), pp. 170-192, March.

Bandyopadhyay, Subhayu, Cletus C. Coughlin, and Howard J. Wall, (2007), "Ethnic Networks and U.S. Exports", Working Papers 2005-069, Federal Reserve Bank of St. Louis.

Bernstein William J. (2008), A Splendid Exchange: How Trade Shaped the World, Atlantic Monthly Press.

Chaney, Thomas (2008), "Distorted Gravity: The Intensive and Extensive Margins of International Trade", American Economic Review, American Economic Association, 98(4), pp. 1707-21, September.

Broda, Christian, and David E. Weinstein (2006), "Globalization and the Gains from Variety”, The Quarterly Journal of Economics, MIT Press, 121(2), pp. 541-585, May.

Coughlin, Cletus C and Wall, Howard J. (2011), Ethnic Networks and Trade: Intensive vs. Extensive Margins, unpublished.

Dunlevy, James A. (2006), "The Influence of Corruption and Language on the Protrade Effect of Immigrants: Evidence from the American States," The Review of Economics and Statistics, MIT Press, 88(1), pp. 182-186, July.

Egger, Peter, Von Ehrlich, Maximilian, and Nelson, Douglas R. (2012), "Migration and Trade", The World Economy, Wiley Blackwell, 35(2), pp. 216$241,02$.

Felbermayr, Gabriel J., and Toubal, Farid (2008), Revisiting the Trade-Migration Nexus: Evidence from New OECD Data.

Felbermayr, Gabriel J, Benjamin Jung and Farid Toubal (2009), "Ethnic Networks, Information, and International Trade: Revisiting the Evidence", 306/2009, Department of Economics, University of Hohenheim, Germany. Girma, Sourafel, and Zhinong Yu (2002), "The Link between Immigration and Trade: Evidence from the United Kingdom”, Weltwirtschaftliches ArchivReview of World Economics, 138, 1, pp. 115-130.

Gould, David M. (1994), "Immigrant Links to the Home Country: Empirical Implications for U.S. Bilateral Trade Flows", The Review of Economics and Statistics, MIT Press, 76(2), pp.302-316, May 
Greif, Avner (1993), "Contract Enforceability and Economic Institutions in Early Trade: the Maghribi Traders' Coalition”, American Economic Review, American Economic Association, 83(3), pp. 525-548, June.

Guiso, Luigi, Sapienza, Paola, and Zingales, Luigi (2009), "Cultural Biases in Economic Exchange", Quarterly Journal of Economics, MIT Press, 124, No.3.

Hatzigeorgiou, Andreas (2010), "Migration as Trade Facilitation: Assessing the Links between International Trade and Migration", The B. E. Journal of Economic Analysis \& Policy, 10: Iss. 1 (Topics), Article 24.

Head, Keith, and John Ries (1998), "Immigration and Trade Creation: Econometric Evidence from Canada", Canadian Journal of Economics, Canadian Economics Association, 31(1), pp. 47-62, February

Herander, Mark G., and Luz A. Saavedra (2005), "Exports and the Structure of Immigrant-Based Networks: The Role of Geographic Proximity," Review of Economics and Statistics 87: pp. 323-335.

Javorcik, Beata S., Ozden, Caglar, Spatareanu, Mariana, and Neagu, Cristina (2011), "Migrant Networks and Foreign Direct Investment", Journal of Development Economics, Elsevier, 94(2), pp. 231-241, March.

Kandogan Yener (2009), "Immigrants, Cross-Cultural Communication and Export Performance: The Swiss Case", European Journal of International Management, 3, 3, pp.393-410.

Kaufmann, Daniel, Kraay, Aart and Mastruzzi, Massimo (2010), "The Worldwide Governance Indicators: Methodology and Analytical Issues", World Bank Policy Research Working Paper No. 5430.

Koenig, Pamina (2009), "Immigration and the Export Decision to the Home Country", PSE Working Papers 2009-31, PSE.

McKenzie, David (2007), "Paper Walls Are Easier to Tear Down: Passport Costs and Legal Barriers to Emigration”, World Development, Elsevier, 35(11), pp. 2026-2039, November.

Mullahy, John (1997), "Instrumental-Variable Estimation of Count Data Models: Applications to Models of Cigarette Smoking Behavior", The Review of Economics and Statistics, 79(4): pp. 586-593.

Neumayer, Eric (2006), "Unequal Access to Foreign Spaces: How States Use Visa Restrictions to Regulate Mobility in a Globalised World", Transactions of the British Institute of Geographers 31 (1), pp.72-84.

Nichols, Austin (2007), "IVPOIS: Stata Module to Estimate an Instrumental Variables Poisson Regression via GMM", available online at http://ideas. repec.org/c/boc/bocode/s456890.html. 
Parsons, R. Christopher, Ronald Skeldon, Terrie L. Walmsley, and L. Alan Winters (2007), "Quantifying International Migration: A Database of Bilateral Migrant Stocks", World Bank Policy Research Working Paper 4165. March.

Peri, Giovanni, and Francisco Requena (2010), "The Trade Creation Effect of Immigrants: Evidence from the Remarkable Case of Spain", Canadian Journal of Economics, Canadian Economics Association, 43(4), pp. 14331459, November.

Rauch, James E. (1996), "Trade and Search: Social Capital, Sogo Shosha, and Spillovers", NBER Working Papers 5618, National Bureau of Economic Research, Inc.

Rauch, James E. (1999), "Networks versus Markets in International Trade", Journal of International Economics, Elsevier, 48(1), pp.7-35, June.

Rauch, James E. (2001), "Business and Social Networks in International Trade", Journal of Economic Literature, American Economic Association, 39(4), pp. 1177-1203, December.

Rauch, James E., and Vitor Trindade (2002), "Ethnic Chinese Networks In International Trade", The Review of Economics and Statistics, MIT Press, 84(1), pp. 116-130, February.

Santos Silva, J. M. C., and Silvana Tenreyro (2006), "The Log of Gravity", The Review of Economics and Statistics, MIT Press, 88(4), pp. 641-658, 09.

TaI, Silvio H. T. (2009), "Market Structure and the Link between Migration and Trade", Review of World Economics, 145, 2, pp. 225-249.

White, Roger, and Tadesse, Bedassa (2008), "Cultural Distance and the US Immigrant-Trade Link”, The World Economy, 31, Issue 8, pp. 1078-1096.

White, Roger (2007), "An Examination of the Danish Immigrant Trade Link", International Migration 45(5): pp. 61-86.

\section{SUMMARY}

This paper uses Swiss immigration data and two novel instrumental variables to test the channels through which migrants promote trade. Using the immigrant stock in France as well as Swiss visa restrictions as instruments for the immigrant stock in Switzerland, I am able to exploit the cross-sectional nature of the data and identify a causal protrade effect. I find robust evidence of a protrade effect that takes place entirely on the extensive margin, i.e. on the number of exported products rather than the value of exports. This suggests migrant networks reduce beachhead costs. I also find that migrants can act as substitute 
for formal institutions, but not so for goods sold on organised markets. This suggests either that differentiated products are not only search- but also trustintensive or that migrants substitute for institutions by providing information rather than trust. 